\title{
Assessment and Seasonal Variations of Heavy Metals and Mineral Elements in River Sokoto, North-western Nigeria
}

\author{
${ }^{* 1}$ M.I.O. Raji, ${ }^{2}$ Y.K.E. Ibrahim, ${ }^{2}$ B.A. Tytler and ${ }^{2}$ J.O. Ehinmidu \\ 1Department of Pharmaceutics and Pharmaceutical Microbiology, Usmanu Danfodiyo University, Sokoto, Nigeria. \\ 2Department of Pharmaceutics and Pharmaceutical Microbiology, Ahmadu Bello University, Zaria, Nigeria.
} ["Corresponding Author: e-mail: rajimuda@gmail.com; P: +2348032845124]

\begin{abstract}
The water quality of River Sokoto in North-western Nigeria was monitored from January, April, June, August, September and November, 2014. Analyses of some selected metals and mineral elements namely $\mathrm{Na}, \mathrm{Mg}, \mathrm{K}, \mathrm{Ca}, \mathrm{Cr}, \mathrm{Mn}, \mathrm{Fe}, \mathrm{Co}, \mathrm{Ni}, \mathrm{Cu}, \mathrm{Zn}, \mathrm{Mo}, \mathrm{Ag}, \mathrm{Cd}, \mathrm{Sn}, \mathrm{Sb}, \mathrm{Hg}$, and Pb from six sampling points was conducted to determine their concentrations in the river during dry (January) and rainy (August) seasons. Analyses of $\mathrm{Na}$ and $\mathrm{K}$ were carried out using Flame Emission Spectroscopy, while other metals were analysed using Atomic Absorption Spectrophotometry (AAS). The elemental concentrations are generally higher in dry season than in the rainy season. Though $\mathrm{Pb}$ was not found in any of the water samples in the dry season, it was found in sample collected from sampling point P4 (a point on stream drainage immediately from Sokoto Cement Factory) at value above WHO's permissible limit in the rainy season. Ag and $\mathrm{Cd}$ were not found in the water samples in rainy season whereas they were found at values above permissible limit in dry season. Hg was found at value above permissible limit in both seasons. The result of T-test analysis shows there was highly significant difference $(\mathrm{p} \leq 0.01)$ in the values of $\mathrm{Mg}, \mathrm{K}, \mathrm{Cr}, \mathrm{Fe}, \mathrm{Co}$, $\mathrm{Ag}, \mathrm{Cd}, \mathrm{Sn}$ and $\mathrm{Hg}$ in all samples for dry and rainy seasons. High level of $\mathrm{Cr}, \mathrm{Co}, \mathrm{Ag}, \mathrm{Cd}, \mathrm{Hg}$ and $\mathrm{Pb}$ in River Sokoto above WHO's permissible limit will certainly have adverse effect on the health of the residents.
\end{abstract}

Keywords: Seasonal variation, heavy metals, mineral elements, pollution, River Sokoto.

\section{INTRODUCTION}

Seasonal variations in quality of water generally refer to the change in components of water, which are to be present at the optimum level for suitable growth of plants and animals. These components play an important role for the growth of plants and animals in the water body. In natural aquatic system, various chemical parameters occur in low concentration. This concentration increases as a result of rapid growth of population, increased urbanisation, industrial activities and exploitation of natural resources (Mehedi et al., 1999). Pollution and contamination of natural water bodies by industrial effluents, agricultural practices and domestic activities have emerged as major challenges in developing and densely populated countries like Nigeria. Many bodies of water in Nigeria experience seasonal fluctuations, leading to a higher concentration of pollutants during the dry season when effluents are least diluted (Kanu et al., 2006). The industrial discharge contributes a larger portion of the flow of the river during the dry season, with the result that water quality of the river is further deteriorated. Surface waters are used for disposal of treated effluents from wastewater treatment plants. These effluents usually contain only small amounts of various contaminants but these harmful components accumulate over time in the river, especially in sediments (Cotman et al., 2001).

Heavy metals in water refers to the heavy, dense, metallic elements that occur in trace levels, but are very toxic and tend to accumulate, hence are commonly referred to as trace metals. They are metallic elements with high atomic weight and density greater than that of water. The major anthropogenic sources of heavy metals are industrial wastes from mining sites, 
Raji etal: Assessment and Seasonal Variations of Heavy Metals and Mineral Elements in

manufacturing and metal finishing plants, domestic waste water and run off from roads. Many of these trace metals are highly toxic to humans, such as $\mathrm{Hg}, \mathrm{Pb}, \mathrm{Cd}, \mathrm{Ni}, \mathrm{As}$, and $\mathrm{Sn}$. Their presence in surface and underground water at above background concentrations is undesirable (Radojavic and Vladimir, 1992). Heavy metals are highly toxic and can cause damage even at very low concentration.

River Sokoto is situated adjacent to the industrial area of the metropolis where industries such as cement, aluminium, fertilizer, foam and tanning factories are found. Most of these factories discharged their effluents into the environment and such discharge end up flowing into the river.

River Sokoto is a major source of water for domestic, agricultural and industrial uses in Sokoto metropolis. Residents along the bank of the river farm crops such as onion, sweet potato, maize, tomatoes and vegetables, and use water from the river to irrigate the crops. Water from this river is also being used for domestic and recreational (swimming) purposes and fishing. Water from River Sokoto is being used for various purposes that may expose the users to some health hazards, thus the need to determine the level of heavy metals and mineral elements it contains for the safety of the users.

\section{Study area}

Sokoto River is a river in north-west Nigeria and a tributary of the River Niger. It has its source near Funtua in the south of Katsina State, some $275 \mathrm{~km}$ in straight line from Sokoto (Hartenbach and Schuol, 2005). It flows north-west passing Gusau in Zamfara State, where the Gusau Dam forms a reservoir that supplies the city with water. Further downstream the river enters Sokoto State where it passes by Sokoto and is joined by the Rima River, then turning south and flowing through Birnin Kebbi in Kebbi State. About 120 $\mathrm{Km}$ south of Birnin Kebbi, it reaches its confluence with the Niger River (Hartenbach and Schuol, 2005). Sokoto metropolis has distinct weather conditions consisting of wet and dry seasons with mean annual rainfall ranging from
$350 \mathrm{~mm}$ to $670 \mathrm{~mm}$ and temperature of $37-40^{\circ} \mathrm{C}$ during dry season.

\section{MATERIAL AND METHODS}

Material used were water samples from six different points on River Sokoto; a point 5 metres away from farmland (P1), a point close to farmland (P2), a point close to residents along the riverside (P3), a point on stream drainage immediately from Sokoto Cement factory (P4), a point on the stream close to the river (P5) and a point 5 metres away on the river (P6). Water samples collected in January, 2014 was used to represent dry season while those collected in August, 2014 represented rainy season. For elemental analyses, surface water samples were gently collected in clean plastic containers and were subjected to preliminarily acidification. This was done by adding 3drops of nitric acid to $100 \mathrm{ml}$ of each sample. Elemental analysis of water samples for $\mathrm{Mg}, \mathrm{Ca}, \mathrm{Cr}, \mathrm{Mn}, \mathrm{Fe}, \mathrm{Co}, \mathrm{Ni}$, $\mathrm{Cu}, \mathrm{Zn}, \mathrm{Mo}, \mathrm{Ag}, \mathrm{Cd}, \mathrm{Sn}, \mathrm{Sb}, \mathrm{Hg}$ and $\mathrm{Pb}$ was carried out with Fast Sequential Atomic Absorption Spectrometer, VARIAN AA 240 FS according to the method of Martin et al., (1994) while $\mathrm{Na}$ and $\mathrm{K}$ were determined with Flame Photometer JENWAY, Model-FPF 7.

\section{RESULTS AND DISCUSSION}

The concentrations of the analysed metals and mineral elements ( $\mathrm{Na}, \mathrm{Mg}, \mathrm{K}, \mathrm{Ca}, \mathrm{Cr}, \mathrm{Mn}, \mathrm{Fe}, \mathrm{Co}$, $\mathrm{Ni}, \mathrm{Cu}, \mathrm{Zn}, \mathrm{Mo}, \mathrm{Ag}, \mathrm{Cd}, \mathrm{Sn}, \mathrm{Sb}, \mathrm{Hg}$ and $\mathrm{Pb}$ ) in water samples for all sampling points in dry (January) and rainy (August) seasons are shown in Tables 1 and 2 respectively. Table 3 shows the result of the T-test analysis of elemental compositions of water samples from River Sokoto in dry and rainy seasons. All water samples for all sampling points contained $\mathrm{Hg}, \mathrm{Ag}$, $\mathrm{Cd}$ and $\mathrm{Fe}$ with values significantly $(\mathrm{P} \leq 0.01)$ on the high side. Generally, there was higher concentration in the dry season than in the rainy season. Also, in this study, $\mathrm{Pb}$ was not found in the water samples in dry season but found in rainy season in sample from sampling point P4 above WHO's permissible limit. The reason for this is not clear. Similarly, $\mathrm{Ag}$ and $\mathrm{Cd}$ were not 


\section{Nigerian Journal of Basic and Applied Science (December, 2016), 24(2): 09-14}

found in rainy season but found above permissible limit in dry season (Tables 1 and 2). This could be due to sedimentation as suggested by Cotman et al. (2001). Surface waters are used for disposal of treated effluents from wastewater treatment plants. These effluents usually contain only small amounts of various contaminants but these harmful components accumulate over time in the river, especially in sediments (Cotman et al., 2001). Muhammad et al. (2014) got similar result and attribute this to the fact that the discharge of heavy metals into rivers by domestic and industrial activities causes their rapid association with particulates and incorporation into bottom sediment.

Muhammad et al. (2014) found the concentration of $\mathrm{Pb}$ in the bottom sediment and floodplain samples of River Bunsuru in Northwestern Nigeria to be significantly high during the rainy season sampling, while $\mathrm{Cu}$ values were consistently high for the rainy and dry seasons. Lead $(\mathrm{Pb})$ was also found at high level in this study. Raji et al. (2010) reported the presence of heavy metals and other elements in relatively high concentrations in the drinking waters in the same geographical zone. In another work by Raji et al. (2015), it was found that water from River Sokoto contained $\mathrm{Hg}, \mathrm{Cd}$ and $\mathrm{Ag}$ and the bottom soil sediments at two sampling points contained $\mathrm{Pb}$ at concentrations above WHO's permissible limit. Chromium ( $\mathrm{Cr}$ ), $\mathrm{Co}$ and $\mathrm{Pb}$ in addition to $\mathrm{Hg}, \mathrm{Cd}$ and $\mathrm{Ag}$ were found in River Sokoto in the recent study. Similar to the result of Radojavic and Vladimir (1992) is also the result of this study where high level of $\mathrm{Cr}, \mathrm{Co}, \mathrm{Ag}, \mathrm{Cd}, \mathrm{Hg}$ and $\mathrm{Pb}$ were found in River Sokoto (Table 3). The presence of chromium and other elements in soaps and detergents used for washing and bathing in the river could be responsible for this.

Elevated concentration of heavy metals in aquatic environment is a good indicator of maninduced pollution (Davies et al., 1991). Studies have shown that use of sewage effluent for irrigation contaminates soil and crops to such an extent that they become harmful to man (Iguisi and Madaki, 2002; Oyinlola and Aliyu, 2005). Sewage effluent contains considerable amount of potentially harmful substances including soluble salts and heavy metals such as $\mathrm{Fe}^{2+}, \mathrm{Cu}^{2+}, \mathrm{Zn}^{2+}$, $\mathrm{Mn}^{2+}, \mathrm{Ni}^{2+}, \mathrm{Pb}^{2+}$. Presence of these heavy metals in water and soil is undesirable. For instance, presence of $\mathrm{Pb}$, in particular in river water that could serve as source of drinking water is of great concern when not properly treated. Lead $(\mathrm{Pb})$ accumulation in River Sokoto may be attributed to massive lead pollution of the river from mining sites in Zamfara State (from where River Sokoto has its source) in the year 2010 (Muhammad et al., 2014). The fact that $\mathrm{Pb}$ plays no biological or physiological role, its presence in sediments at whatever concentration poses threat to fishes in aquatic environment because of the bottom feeding habits of the aquatic organism (Muhammad et al., 2014). Also, plants can accumulate heavy metals in their tissues in concentrations above the permitted level which is considered to represent a threat to the life of humans and animals feeding on these crops and may lead to contamination of food chain (Adnan, 2010). 
Raji etal: Assessment and Seasonal Variations of Heavy Metals and Mineral Elements in

Table1: Concentration of Elements in Water from Different Sampling Points on River Sokoto in Dry Season

\begin{tabular}{|c|c|c|c|c|c|c|c|}
\hline \multirow{2}{*}{ Element } & \multicolumn{6}{|c|}{ Concentration at sampling points (mg/L) } & \multirow{2}{*}{$\begin{array}{c}\text { WHO } \\
\text { Guideline } \\
\text { (mg/L) }\end{array}$} \\
\hline & P1 & $\mathrm{P} 2$ & P3 & P4 & P5 & P6 & \\
\hline $\mathrm{Na}$ & $180.00 \pm 0.00$ & $230.00 \pm 0.00$ & $180.00 \pm 0.00$ & $200.00 \pm 0.00$ & $180.00 \pm 0.00$ & $200.00 \pm 0.00$ & NP \\
\hline $\mathrm{Mg}$ & $28.90 \pm 0.01$ & $30.82 \pm 0.00$ & $32.02 \pm 0.00$ & $35.77 \pm 0.00$ & $32.49 \pm 0.00$ & $31.68 \pm 0.00$ & NP \\
\hline $\mathrm{K}$ & $80.00 \pm 0.00$ & $90.00 \pm 0.00$ & $60.00 \pm 0.00$ & $70.00 \pm 0.00$ & $70.00 \pm 0.00$ & $50.00 \pm 0.00$ & NP \\
\hline $\mathrm{Ca}$ & $83.02 \pm 0.00$ & $105.47 \pm 0.00$ & $102.20 \pm 0.00$ & $458.53 \pm 0.00$ & $227.66 \pm 0.00$ & $100.85 \pm 0.00$ & NP \\
\hline $\mathrm{Cr}$ & $0.000 \pm 0.00$ & $0.000 \pm 0.00$ & $0.000 \pm 0.00$ & $0.000 \pm 0.00$ & $0.000 \pm 0.00$ & $0.000 \pm 0.00$ & 0.05 \\
\hline $\mathrm{Mn}$ & $0.000 \pm 0.00$ & $0.000 \pm 0.00$ & $0.000 \pm 0.00$ & $0.000 \pm 0.00$ & $0.000 \pm 0.00$ & $0.000 \pm 0.00$ & 0.5 \\
\hline $\mathrm{Fe}$ & $44.33 \pm 0.00^{*}$ & $35.15 \pm 0.00^{*}$ & $44.37 \pm 0.00^{*}$ & $11.64 \pm 0.00^{*}$ & $10.11 \pm 0.00^{*}$ & $30.13 \pm 0.00^{*}$ & 0.3 \\
\hline Co & $0.000 \pm 0.00$ & $0.000 \pm 0.00$ & $0.000 \pm 0.00$ & $0.000 \pm 0.00$ & $0.000 \pm 0.00$ & $0.000 \pm 0.00$ & $N G$ \\
\hline $\mathrm{Ni}$ & $0.000 \pm 0.00$ & $0.000 \pm 0.00$ & $0.000 \pm 0.00$ & $0.000 \pm 0.00$ & $0.000 \pm 0.00$ & $0.000 \pm 0.00$ & 0.02 \\
\hline $\mathrm{Cu}$ & $0.056 \pm 0.00$ & $0.505 \pm 0.00$ & $0.306 \pm 0.00$ & $0.173 \pm 0.00$ & $0.736 \pm 0.00$ & $0.064 \pm 0.00$ & 2.0 \\
\hline $\mathrm{Zn}$ & $0.076 \pm 0.00$ & $0.278 \pm 0.00$ & $0.360 \pm 0.00^{*}$ & $1.028 \pm 0.00$ & $0.210 \pm 0.00$ & $0.311 \pm 0.00^{*}$ & 0.3 \\
\hline Mo & $2.57 \pm 0.00^{*}$ & $0.000 \pm 0.00$ & $0.000 \pm 0.00$ & $0.000 \pm 0.00$ & $0.000 \pm 0.00$ & $0.000 \pm 0.00$ & 0.07 \\
\hline $\mathrm{Ag}$ & $3.60 \pm 0.00^{*}$ & $3.53 \pm 0.00^{*}$ & $3.72 \pm 0.00^{*}$ & $3.26 \pm 0.00^{*}$ & $2.49 \pm 0.00^{*}$ & $2.57 \pm 0.00^{*}$ & 0.1 \\
\hline $\mathrm{Cd}$ & $1.35 \pm 0.00^{*}$ & $1.38 \pm 0.00^{*}$ & $1.43 \pm 0.00^{*}$ & $1.42 \pm 0.00^{*}$ & $1.34 \pm 0.00^{*}$ & $1.54 \pm 0.00^{*}$ & 0.003 \\
\hline Sn & $96.41 \pm 0.00$ & $78.27 \pm 0.00$ & $54.92 \pm 0.00$ & $43.32 \pm 0.00$ & $53.55 \pm 0.00$ & $41.48 \pm 0.00$ & NG \\
\hline $\mathrm{Sb}$ & $0.000 \pm 0.00$ & $0.000 \pm 0.00$ & $0.000 \pm 0.00$ & $0.000 \pm 0.00$ & $0.000 \pm 0.00$ & $0.000 \pm 0.00$ & 0.005 \\
\hline $\mathrm{Hg}$ & $80.15 \pm 0.00^{*}$ & $83.39 \pm 0.00^{*}$ & $287.37 \pm 0.00^{*}$ & $142.52 \pm 0.00^{*}$ & $105.54 \pm 0.00^{*}$ & $165.08 \pm 0.0^{*}$ & 0.001 \\
\hline $\mathrm{Pb}$ & $0.000 \pm 0.00$ & $0.000 \pm 0.00$ & $0.000 \pm 0.00$ & $0.040 \pm 0.00$ & $0.000 \pm 0.00$ & $0.000 \pm 0.00$ & 0.01 \\
\hline
\end{tabular}

Key:

$*=$ Level above permissible limit. NP $=$ No value is proposed. NG $=$ Not mentioned in the WHO (2003) Guideline

Table 2: Concentration of Elements in Water from Different Sampling Points on River Sokoto in Rainy Season

\begin{tabular}{|c|c|c|c|c|c|c|c|}
\hline \multirow{2}{*}{ Element } & \multicolumn{6}{|c|}{ Concentration at sampling points (mg/L) } & \multirow{2}{*}{$\begin{array}{c}\text { WHO } \\
\text { Guideline } \\
\text { (mg/L) }\end{array}$} \\
\hline & $\mathrm{P} 1$ & $\mathrm{P} 2$ & P3 & P4 & P5 & P6 & \\
\hline $\mathrm{Na}$ & $31.00 \pm 0.00$ & $27.00 \pm 0.00$ & $29.00 \pm 0.00$ & $47.00 \pm 0.00$ & $44.00 \pm 0.00$ & $27.00 \pm 0.00$ & NP \\
\hline $\mathrm{Mg}$ & $0.699 \pm 0.01$ & $0.707 \pm 0.00$ & $0.706 \pm 0.00$ & $0.728 \pm 0.00$ & $0.745 \pm 0.00$ & $0.780 \pm 0.00$ & NP \\
\hline K & $62.00 \pm 0.00$ & $9.00 \pm 0.00$ & $40.00 \pm 0.00$ & $18.00 \pm 0.00$ & $33.00 \pm 0.00$ & $9.00 \pm 0.00$ & NP \\
\hline $\mathrm{Ca}$ & $0.362 \pm 0.00$ & $0.378 \pm 0.00$ & $0.342 \pm 0.00$ & $1.496 \pm 0.00$ & $0.948 \pm 0.00$ & $1.573 \pm 0.00$ & NP \\
\hline $\mathrm{Cr}$ & $0.063 \pm 0.00^{*}$ & $0.135 \pm 0.00^{*}$ & $0.149 \pm 0.00^{*}$ & $0.044 \pm 0.00$ & $0.061 \pm 0.00^{*}$ & $0.076 \pm 0.00^{*}$ & 0.05 \\
\hline $\mathrm{Mn}$ & $0.000 \pm 0.00$ & $0.000 \pm 0.00$ & $0.000 \pm 0.00$ & $0.000 \pm 0.00^{*}$ & $0.000 \pm 0.00$ & $0.001 \pm 0.00$ & 0.5 \\
\hline $\mathrm{Fe}$ & $0.760 \pm 0.00^{*}$ & $0.518 \pm 0.00^{*}$ & $0.565 \pm 0.00^{*}$ & $0.000 \pm 0.00$ & $0.213 \pm 0.00$ & $0.166 \pm 0.00$ & 0.3 \\
\hline Co & $0.044 \pm 0.00$ & $0.050 \pm 0.00$ & $0.041 \pm 0.00$ & $0.039 \pm 0.00$ & $0.047 \pm 0.00$ & $0.049 \pm 0.00$ & NG \\
\hline $\mathrm{Ni}$ & $0.010 \pm 0.00$ & $0.005 \pm 0.00$ & $0.007 \pm 0.00$ & $0.014 \pm 0.00$ & $0.001 \pm 0.00$ & $0.010 \pm 0.00$ & 0.02 \\
\hline $\mathrm{Cu}$ & $0.014 \pm 0.00$ & $0.009 \pm 0.00$ & $0.011 \pm 0.00$ & $0.007 \pm 0.00$ & $0.011 \pm 0.00$ & $0.008 \pm 0.00$ & 2.0 \\
\hline $\mathrm{Zn}$ & $0.031 \pm 0.00$ & $0.032 \pm 0.00$ & $0.070 \pm 0.00$ & $0.036 \pm 0.00$ & $0.027 \pm 0.00$ & $0.054 \pm 0.00$ & 0.3 \\
\hline Mo & $0.024 \pm 0.00$ & $0.000 \pm 0.00$ & $0.000 \pm 0.00$ & $0.000 \pm 0.00$ & $0.000 \pm 0.00$ & $0.000 \pm 0.00$ & 0.07 \\
\hline $\mathrm{Ag}$ & $0.008 \pm 0.00$ & $0.000 \pm 0.00$ & $0.000 \pm 0.00$ & $0.000 \pm 0.00$ & $0.000 \pm 0.00$ & $0.000 \pm 0.00$ & 0.1 \\
\hline $\mathrm{Cd}$ & $0.002 \pm 0.00$ & $0.000 \pm 0.00$ & $0.000 \pm 0.00$ & $0.000 \pm 0.00$ & $0.000 \pm 0.00$ & $0.000 \pm 0.00$ & 0.003 \\
\hline Sn & $1.426 \pm 0.00$ & $1.165 \pm 0.00$ & $0.036 \pm 0.00$ & $0.014 \pm 0.00$ & $0.032 \pm 0.00$ & $0.012 \pm 0.00$ & NG \\
\hline $\mathrm{Sb}$ & $0.000 \pm 0.00$ & $0.000 \pm 0.00$ & $0.000 \pm 0.00$ & $0.000 \pm 0.00$ & $0.000 \pm 0.00$ & $0.000 \pm 0.00$ & 0.005 \\
\hline $\mathrm{Hg}$ & $2.989 \pm 0.00^{*}$ & $1.828 \pm 0.00^{*}$ & $1.411 \pm 0.00^{*}$ & $1.732 \pm 0.00^{*}$ & $1.366 \pm 0.00^{*}$ & $1.516 \pm 0.00^{*}$ & 0.001 \\
\hline $\mathrm{Pb}$ & $0.000 \pm 0.00$ & $0.000 \pm 0.00$ & $0.000 \pm 0.000$ & $0.069 \pm 0.000^{*}$ & $0.000 \pm 0.000$ & $0.000 \pm 0.000$ & 0.01 \\
\hline
\end{tabular}

Key:

${ }^{*}=$ Level above permissible limit. NP $=$ No value is proposed. $N G=$ Not mentioned in the WHO (2003) Guideline. 


\section{Nigerian Journal of Basic and Applied Science (December, 2016), 24(2): 09-14}

Table 3: T-test Analysis of Elemental concentrations of water samples from different points on River Sokoto in dry and rainy seasons

\begin{tabular}{|c|c|c|c|c|}
\hline \multirow[t]{2}{*}{ Element } & \multicolumn{2}{|c|}{ Mean \pm SD } & \multirow[t]{2}{*}{ Level of significance } & \multirow[t]{2}{*}{ t-value } \\
\hline & Dry Season & Rainy Season & & \\
\hline $\mathrm{Na}$ & $195.00 \pm 19.75$ & $34.17 \pm 8.95$ & $0.000^{*}$ & 18.17 \\
\hline $\mathrm{Mg}$ & $31.95 \pm 2.26$ & $0.73 \pm 0.03$ & $0.000^{* *}$ & 33.83 \\
\hline K & $70.00 \pm 14.14$ & $28.50 \pm 20.72$ & $0.002^{* *}$ & 4.05 \\
\hline $\mathrm{Ca}$ & $179.62 \pm 146.37$ & $0.85 \pm 0.58$ & $0.014^{*}$ & 2.99 \\
\hline $\mathrm{Cr}$ & $0.00 \pm 0.00$ & $0.09 \pm 0.05$ & $0.001^{* *}$ & -4.73 \\
\hline $\mathrm{Mn}$ & $0.00 \pm 0.00$ & $0.00 \pm 0.00$ & . & - \\
\hline $\mathrm{Fe}$ & $29.29 \pm 15.28$ & $0.37 \pm 0.29$ & $0.001^{* *}$ & 4.63 \\
\hline Co & $0.00 \pm 0.00$ & $0.05 \pm 0.01$ & $0.000^{* *}$ & -22.53 \\
\hline $\mathrm{Ni}$ & $0.00 \pm 0.00$ & $0.01 \pm 0.01$ & $0.010^{*}$ & -3.16 \\
\hline $\mathrm{Cu}$ & $0.31 \pm 0.27$ & $0.01 \pm 0.00$ & $0.023^{*}$ & 2.69 \\
\hline $\mathrm{Zn}$ & $0.38 \pm 0.33$ & $0.04 \pm 0.02$ & $0.033^{*}$ & 2.47 \\
\hline $\mathrm{Ag}$ & $3.20 \pm 0.54$ & $0.00 \pm 0.00$ & $0.000^{* *}$ & 14.56 \\
\hline $\mathrm{Cd}$ & $1.41 \pm 0.07$ & $0.00 \pm 0.00$ & $0.000^{* *}$ & 47.18 \\
\hline Sn & $61.34 \pm 21.61$ & $0.44 \pm 0.66$ & $0.000^{* *}$ & 6.90 \\
\hline $\mathrm{Sb}$ & $0.00 \pm 0.00$ & $0.00 \pm 0.00$ & - & - \\
\hline $\mathrm{Hg}$ & $144.01 \pm 77.76$ & $1.81 \pm 0.61$ & $0.001^{* *}$ & 4.48 \\
\hline $\mathrm{Pb}$ & $0.00 \pm 0.00$ & $0.00 \pm 0.01$ & 0.341 & -1.00 \\
\hline
\end{tabular}

Difference is not significant at $p>0.05$

${ }^{*}$ Difference is significant at $p \leq 0.05$

${ }^{* *}$ Difference is highly significant at $p<0.01$

\section{CONCLUSION}

Water of River Sokoto contained Cr, Co, Ag, Cd, $\mathrm{Hg}$ and $\mathrm{Pb}$ at concentrations above permissible limits. Furthermore, the concentrations of the elements were generally higher in dry season than in rainy season. Because fishes accumulate metals in their bodies, man who subsequently feed on them is at risk. Government should therefore put in place laws that guide mining practices in the area. People and industries should also be enforced to abide by rules and regulations governing waste management and disposal.

\section{REFERENCES}

Adnan A., Taufeeq, A., Malik, E., Irfanullah, M., Masror, K. \& Muhammad, A.K. (2010) Evaluation of industrial and city effluent quality using physicochemical and biological parameters, Electronic Journal of Environmental, Agricultural and Food Chemistry, 9(5): 931-939.

Cotman M; Zagorc-Koncan J. and Droic A. (2001) Study of impacts of treated wastewater to the Krka River, Slovenia.

Water Science Technology; 44(6): 47-54. Davies, C.A., Tomlinson, K. and Stephenson, T. (1991). Heavy metals in river Tees estuary sediments. Environmental Technology, 12: 961-972

Hartenbach, A. and Schuol, J. (2005) Bakolori Dam and Bakolori Irrigation ProjectSokoto River, Nigeria. American Journal of Public Health, 76, 407-410.

Iguisi, E. O. \& Madaki, C. N. (2002) An Assessment of the Levels of Toxicity of Industrial Effluents from some Industrial Establishments in Kaduna Metropolis.

Proceedings of the First National Conference of Environmental Science.

Kanu, I.,Achi, O.K.,Ezeronye, O.U. \& Anyanwu, E.C. (2006). Seasonal variation in bacterial heavy metal biosorption in water samples from Eziama River near soap and brewery industries and the environmental health implications. International Journal of Environmental Science and Technology, 3(1): 95-102. 
Martin, T.D.; Creed, J.T. \& Brockhoff, C.A. (1994). EPA Method 200.2; Sample Preparation Procedure for Spectrochemical Determination of Total Recoverable Elements, Methods for the Determination of Metals in Environmental Samples, Supplement I, EPA/600/R94/111, EPA, Cincinnati, OH.

Mehedi, M.Y.; Kamal, D.; Azam, K. \& Khan, Y.S.A. (1999). Trace metals in coastal water along the ship breaking area, Chittagong, Bangladesh. Khulna University Studies, 1: 289-293.

Muhammad, H.L., R.A. Shehu, L.S. Bilbis \& S.M. Dangoggo (2014).Analyses of selected Heavy Metals and Mineral Elements in Pollution Prone Aquatic Environments of North-Western Region of Nigeria. Asian Journal of Biological Sciences, 7(6): 252-261.

Oyinlola, E. Y. and Aliyu, I. A. (2005) Effect of town waste and fertilizer on growth and heavy metal concentration of tomato plant. ChemClass Journal, 2: 32-35.

Raji, M.I.O., Ibrahim, Y.K.E., Ehinmidu, J.O. (2010). Physico-chemicalcharacteristics and heavy metal levels in drinking water sources in Sokoto metropolis in Northwestern Nigeria. Journal of Applied Science and Environmental Management.,14(3): 81-85.

Raji, M.I.O., Ibrahim, Y.K.E., Tytler, B.A., \& Ehinmidu, J.O. (2015). Analyses of selected heavy metals and mineral elements in pollution prone River Sokoto in Northwestern Nigeria. Journal of Pure and Applied Sciences, 3(4): 91-97.

Radojavic, M. and Vladimir, N.B. (1992) Bulletin of the Royal society of chemistry, London, pp14

WHO (2003).Guidelines for Drinking-water Quality.3rded. Chapter 8, DRAFT. Geneva, World HealthOrganization. 